\title{
Problems and Crisis of Islamic Education Today and in The Future
}

\author{
Hisbullah \\ State Islamic Institute of Palopo (IAIN Palopo), Indonesia \\ *e-mail: hisbullah@iainpalopo.ac.id
}

\begin{tabular}{l}
\hline \multicolumn{1}{c}{ Article Information } \\
\hline Received: March 10, 2020 \\
Revised: May 21, 2020 \\
Online: June 26, 2020 \\
\hline \multicolumn{1}{c}{ Keywords } \\
\hline $\begin{array}{l}\text { Islamic education, problems of } \\
\text { education, the product of human } \\
\text { reason }\end{array}$
\end{tabular}

\begin{tabular}{l} 
ABSTRACT \\
\hline Islamic strategies and tactics must be more effective and \\
efficient, meaning pedagogical, sociological, and cultural. \\
Therefore, the Islamic breath in the person of a Muslim is \\
essential to be able to move the behaviour reinforced with \\
extensive knowledge so that he can provide appropriate and \\
useful answers to the challenges of the development of science \\
and technology, and in Islamic education will not be separated \\
from Islamic principles sourced from the basic principles of \\
the Koran. Planning for future education must include three \\
main characteristics of a society, namely: the future of socio, \\
the future of techno, and the future of bio. Besides, Islamic \\
education strategies in facing future challenges include: (1) \\
Building an actual Islamic Education paradigm; (2) Carry out \\
Affective Education; and (3) Improving the quality of teaching \\
staff.
\end{tabular}

\section{INTRODUCTION}

The term Islamic Education is used in two ways, namely: first, all activities carried out by a person or institution to instill Islamic values in several students. Second, the whole educational institution, which is based on all programs and activities of Islamic views and values. (Arifin, 1991)

As a Muslim-majority country, Islamic education has a very significant role in Indonesia in the development of human resources and character development, so that the society created is a reflection of Islamic civilization. Thus Islam truly becomes rahmatan lil-alamin, a blessing for all nature. It can be understood that Islamic education aims to prepare students to become human beings who can live happily in the world and the hereafter. And to be able to prepare students to live happily in the world and the heaven not only by providing public education but also by giving and instilling Islamic religious values in these students so that with religious education can control all their behavior in the world and can save his life in the hereafter. As the word of Allah Most High in Q.S. Al-Qashash 28: 77:

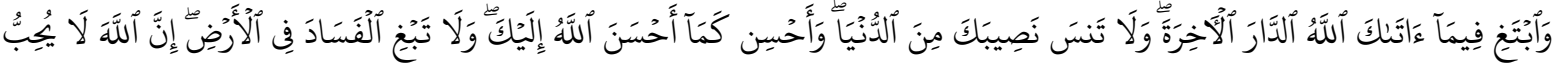

$$
\begin{aligned}
& \text { أَلْفُفِيدِينَ }
\end{aligned}
$$

But seek, through that which Allah has given you, the home of the hereafter; and [yet], do not forget your share of the world. And do good as Allah has done well to you. And desire, not corruption in the land. Indeed, Allah does not like corrupters."

However, until now Islamic education still faces complex problems, from conceptual-theoretical problems to operational-practical problems. The unresolved issue made Islamic education lag behind other educational institutions, both quantitatively and qualitatively, so that Islamic education was impressed as "second class" education. No wonder then that many of the Muslim generations actually went to school in non-Islamic educational institutions. 
Besides, the overlapping orientation of Islamic education gave birth to significant problems in the world of education, from philosophical issues to methodological issues. Besides that, Islamic culture faces a severe challenge related to changes in society that are continually accelerating, especially the development of science, which hardly cares anymore about the system of religion. (Zamroni, 2000)

At present conditions, Islamic education is in a position of historical determinism and realism. In the sense that one side of the Islamic ummah is in historical romance where they are proud of having had great thinkers or scientists and had a significant contribution to the development of world civilization and science as well as being a transmission for the Greek treasures. Still, on the other hand, they face the reality that Islamic education is powerless confronted with the reality of modern industrial and technological society.

The existing Islamic education system only works on the religious sciences. On the other hand, generations of Muslims who take education outside the Islamic education system only get a small portion in terms of Islamic culture or even not at all getting Islamic sciences.

\section{METHODS}

The research method used in this study is library research done by collecting articles or scientific papers related to learning planning, learning design, learning model. This research is qualitative, by observing phenomena in Indonesia, formulating problems that occur, and then related to the obtained literature. Data collection techniques are performed by tri-formulating (combined) literature review by collecting data, exceptionally verbal data, through books, articles, notes, and various other scientific literature. The data collected are then analyzed inductively to produce grounded theory, a theory that emerges from non-hypothesis data (Setyosari, 2013). Writing steps to prepare this article: 1) Choosing a problem; 2) a preliminary study; 3) formulating a problem; formulating objectives; 4) conducting a study; 5) making a discussion; 6) formulating conclusions drawn from analysis results and recommendations for other authors.

\section{RESULTS}

The problem of Islamic education today is related to the lagging of Islamic learning, which is caused by the narrowing of the understanding of Islamic knowledge, which is only in the aspect of Sahrawi life that is separate from worldly life, or aspects of spiritual life that are separate from physical life. Then the difference and separation between what is considered religion and not religion will be seen. This perspective, which separates from one another, is called the dichotomous pandanus method.

The cause of Islamic education is left behind today because Islamic education still separate reason and revelation, as well as the needy and remembrance. This causes a paradigmatic imbalance, which is the lack of the development of the concept of humanism in Islamic education at the same time because Islamic culture is more oriented to the idea of 'abdullah (man as a servant), rather than as the concept of khalifatullah (man as the caliph of God). Besides that, the overlapping orientation of Islamic education gave birth to significant problems in the world of education, from philosophical issues to methodological issues. Besides that, Islamic culture faces a severe challenge related to changes in society that are continually accelerating, especially the development of science, which hardly cares anymore about the system of religion. (Sanaky, 1997)

According to Baharudin, there are several weaknesses as well as problems of Islamic education facing the era of globalization, namely: (1) The quality of Islamic educational institutions, in general, is still pathetic. Although there are some Islamic educational institutions such as madrasas that have been able to surpass the quality of public schools, in general, the quality of Islamic educational institutions is inadequate; (2) The image of Islamic educational institutions is relatively low. It is a fact that in the graduation rank of Islamic educational institutions are generally ranked below public schools; (3) Inadequate quality and quantity of teachers. The teacher is the key to success in education. If the teacher is of poor quality and the student ratio is inadequate, the education output will naturally be low too; (4) Teacher salaries, in general, are still small; (5) Background of students in Islamic educational institutions in general from lower-middle-class families; (6) Increasing demands for competition and competence; (7) The onslaught of the influence of foreign globalization in the economic, political and cultural fields which tends to shift the national religious culture. This is marked by the increasingly prominent global orientation in the areas of fun, fashion, and food among our teenagers; (8) Juvenile 
delinquency that is increasingly worrying, among others, in the form of widespread drug abuse; and (9) The hope of the ummah that Islamic educational institutions can give birth to those who are intellect, but pious and those who are intellectual.

It can be seen that there are two problems faced by Islamic educational institutions, namely internal and external. In the subjective aspect, challenges faced are related to (1) Quality, administration and management of madrassas generally cannot produce quality graduates; (2) Educators, the majority of educators and education staff in madrasas, are not yet qualified following statutory demands; (3) Curriculum, most madrassas have not been able to implement content standards and have not been able to reach the minimum graduate competency standards fully. The percentage of national exam graduates is quite encouraging, approximately $92 \%$, but the average score is still 51; (4) Management, administration, and management of madrassas, which are $91.4 \%$ private, generally have not been managed with professional management; (5) Infrastructure facilities, inadequate facilities and infrastructure in most madrasas; and (6) Status, not yet fully confident in the management and implementation and limited opportunities for enforcement so that public madrassas which generally meet minimum standards, only amount to $8.6 \%$. The problem of Islamic education on the external aspect is the perception of society and government that tends to be discriminatory, so that madrassas receive less attention, including in the provision of the budget, and some even consider it as a secondclass educational institution after school. (Langgulung, 1980)

The orientation of Islamic education and the technological age of the future also needs to be changed both regarding systems and methods. The breath of Islam in the person of a Muslim is a vital tool that drives behavior that is strengthened by extensive science so that he can provide appropriate and useful answers to the challenges of the development of science and technology.

If we look at the institution of Islamic education is a sub-system of the community or nation system. In its operation, it always refers and responds to the needs and development of the city. This is to avoid socio-cultural gaps. To find out between educational institutions and the community regarding increased needs is to do an assessment.

The weakness of the function of the institution of the sub-system of society is fundamentally inseparable from the mechanism of the socio-cultural system, which is currently in tandem with the influence of science and technology itself. Besides that, the shift in the sense of community towards the rational-technological mindset that tends to break away from cultural-educative traditionalism is increasingly swelling. So the function of the institution must be more latent towards the social inclination. (Azra, 2002)

In the present and future era, the view of respecting human values is increasingly concerned with the renewal planners, avoiding the widespread domination of technology robots that have an uncertain outcome. If this problem is not well anticipated, it will have a devastating effect on Islamic education in the future.

One of the reasons for the backwardness of Islamic education is the narrowing of the understanding of Islamic education which only revolves around the aspects of ukhrawi life that are separate from worldly life, or aspects of spiritual life that are separate from physical life.

Therefore, it will appear that there is a difference and separation between what is considered religion and non-religion, the sacred and the profane, between the world and the hereafter. This perspective that separates one another is called a dichotomous viewpoint. The existence of this dichotomy is one of the causes of the backwardness of Islamic education. Until now, Islamic education still separates between reason and revelation, as well as thought and dhikr. This causes an imbalance of thought patterns, namely the lack of development of the concept of religious humanism in the world of Islamic education, because Islamic education is more oriented towards the concept of 'abdullah (man as servant), rather than as the concept of khalifatullah (man as the caliph of Allah). (Nata, 2003)

It is this sorting between general science and religious knowledge that brings Muslims to the backwardness and decline of civilization, because general knowledge is considered something that is outside of Islam and comes from non-Islam or the other, and is often opposed between religion and science (in this case science).

Religion is considered to have nothing to do with science, so science is considered ignorant of religion. That is the description of educational practice and scientific activities in the country today with various negative impacts caused and felt by the community. 
The existing Islamic education system only teaches religious sciences. On the other hand, the Muslim generation who took education outside the Islamic education system only received a small portion in terms of Islamic education or even did not get Islamic knowledge at all. (Mastuhu, 1999)

\section{DISCUSSION}

\section{Solution to the Problems of Today's Islamic Education}

Observing this reality, the problem of the concept of dualism-dichotomic education must be immediately subverted and resolved, both at the philosophical-paradigmatic and departmental technical levels. The philosophical thought becomes significant because this thought will later provide a worldview that becomes an ideological and moral basis for education (Ilham, 2020).

The separation between science and religion should be immediately stopped and become an effort to unite the two in an integralists education system. But the issue of the integrity of science and religion in an early education system is not an easy problem. Still, it must be based on healthy philosophical thinking so that it does not seem merely patchy. The initial step that must be taken in making educational changes is to formulate a "philosophical basic framework of education" following Islamic teachings, then to develop "empirically the principles" that underlie implementation in the context of the environment (socio-cultural)

\section{System Approach and Orientation}

The Islamic education approach views that the ultimate truth of Islam must be able to defeat the rampant outrage outside of Islamic life based on the above argument. Still, the absolute truth can develop fully in society if its adherents try hard and right on target through effective and efficient system methods.

The effectiveness and efficiency of Islam, according to us to apply various engineering based on theoretical and practical knowledge following the goals worked on. Because Islamic education today is faced with challenges far more substantial than the challenges faced at the beginning of the spread of Islam. This is caused by the increasing demand (rising demand) of various kinds of leisure and greater pleasure, entering the spaces and gaps in our lives until the dim and even dark can be penetrated. In Q.S. Al-Isra 17: 81, as follows:

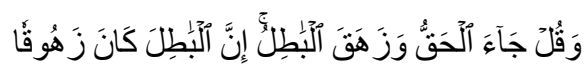

And say, the truth has come, and falsehood has departed. Indeed is falsehood, [by nature], ever bound to depart."

The negative impact of modern technology has begun to appear before our eyes. In principle, the power to weaken the mental-spiritual power or soul that is growing and developing in various forms of appearance and lifestyle. Besides, the physical becomes a target, such as intelligence of mind, memory, will, and feeling (emotion) weakened. Its actual capability is facilitated by electronic-technological and information technology devices such as computers, remote copies (facsimiles), video cassette recorders (VCRs), and celluloid commodities (video-disc films), and so on.

Soon, our students will no longer need to learn foreign languages or hand skills, and to have a high level of scientific thinking, because technological tools have been able to replace them with computer translators of all foreign languages. Robots are ready to do the tasks that have to be done by hand or brain machines (new generation computers) can think faster than the human brain itself. Then, how about the process of internalizing and transforming the values of faith and piety into the depths of the human heart. Until now, we have not heard of the technology of the transformation of spiritual values. New problems that must be solved by Islamic education, in particular, are the dehumanization of schooling, the neutralization of religious values, or the control effort of directing transitional amounts to a divine, sturdy and resilient settlement, both individual and socio-cultural dimensions. (Sanaky, 1997)

2. Institutionalizing the Islamic Education Process

Islamic education that takes place through operational processes towards its objectives requires a consistent model and system that can support the moral-spiritual values that underlie it. These values are actualized based on the orientation of the development needs of the students' nature that is 
integrated with the influence of the existing cultural environment. Therefore, the institutional management of Islamic Education views that the entire educational process within an institution is a system that is oriented towards actual actions based on a systematic approach. Institutional Islamic education is a sub-system of the community or nation system. In operation, it always refers and responds to the development needs of the city. Without this attitude, this gap is one of the sources of conflict between education and society. From there arises an educational crisis whose intensity varies according to the level or level of organization. In the present and future technological era, the view of the appreciation of human values is increasingly becoming a concern of the planners of the renewal movement, avoiding the widespread dominance of unsustainable technological robots. Education that is used as a basis for human hope must be able to project future conditions into three categories, namely:

a. The Future of Socio

They contain principal phenomena, among others, the slow spread of alternative household structures, parental care by parents, views about motherhood, relationships about sexuality and new social morality, and reinterpretation of the role of religion in society. More and more women are becoming workers. Life press on social aspects, a general rejection of the use of weapons of mass destruction (nuclear and chemical). Inter-ethnic and religious marriages occur. The radicalism of students is decreasing. Status is less associated with consumer objects. The solution to the long-term energy crisis has never been reached, and per capita, energy use has declined; zero population growth is increasingly favored by mothers; increasingly expanding with new forms of transportation; promiscuity and pornography will come; increasingly expanding with new ways of transportation; promiscuity and pornography will remain tolerated; television is frequently being used for the introduction of more active cultures and so on.

b. The Future of Techno

In short, it can be concluded that the future of society will be affected by the influence of high physical energy, innovation, and its application, which tends to be higher towards laser beam energy. Increased use of computers and data processing techniques, improvement of household computers, the introduction of superconductors in electrical transmission, and the introduction of non-wires. Increased awareness that technology is unable to find replacements for power sources such as fuel, minerals, and fresh air. International trade and investment have emerged as a global force for world peace and stability. Engineering companies will incur more losses than profits in the range of armaments.

c. The Future of Bio

Principally, it is marked by the growing discussion about the use of behavioral modification techniques such as chemistry, electronics, and psychology, as well as genetic manipulation issues. The decline in the range of life caused by food shortages and environmental pollution and the declining rate of infant mortality are marked. But it seems to us that the future of human life continues to rely on formal and non-formal educational institutions as centers of development and control of modern human tendencies towards optimism. Primarily if the trend is based on moral and religious values, therefore, education can still be groomed with potential for the development of human development far in the future seen from various reasons of sociology, psychology, culture, and technology.

3. Principles of Islamic Education as a Discipline of Science

As a scientific discipline, Islamic education has the main task of gaining insight or views on education contained in the primary sources. In these primary sources, there are structural materials that contain educational resources or educational implications that are still scattered. For that to form an Islamic education, the content needs to be systematized and theorized following the rules contained in the world of education (Muslim, 2008). The science of Islamic culture, in particular, is composed of concepts and theories which are systematized into roundness consisting of one interrelated component. Islamic education is a collection of intellectual ideas and concepts that are arranged and strengthened through experience and knowledge. In other words, the science of Islamic culture must rely on ideological views and practical experience consisting of facts and information to be processed into valid theories on which exact science is based. Three necessary components must be discussed in the education component, including:

a. The goal of Islamic education must be formulated and clearly and equally defined for all Muslims so that it is universal. As the essence of the purpose of Islamic scholarship that is in line with the Qur'an, it is none other than surrender entirely to God Almighty. 
b. The Islamic education method that we created must function effectively in the process of achieving the goals of Islamic education. The comprehensiveness of the educational objectives must be parallel with the diversity of methods, ranging from the way of verbalistic-symbolism to direct interaction in the atmosphere of teaching and learning.

c. Harmonic movement rhythms between methods and educational objectives in the process will experience a vacuum if without the presence of values or ideas. Therefore Islamic education must lead to the development of human qualities as Khalifah on earth.

In the content (curriculum) of Islamic education must reflect the types of science needed by Muslim humans to support their duties as mandates of God on earth. Based on the above ideas, Islamic culture as a scientific discipline has a potential capital base to be developed so that it can play a role in the heart of today's dynamic society and the future. In scientific studies, science must rely on theories. Therefore the method of Islamic education must meet the following requirements:

1. The theory must establish the existence of a relationship between facts and existing.

2. Theories must develop classification systems and structures from concepts.

3. The theory must be interpreted as fact.

4. The theory must predict a fact and events

The abstract style of education is intended to be arranged in a systematic, well-organized manner, which can describe the facts of operational experience in the form of a simple understanding as possible.

From the various problems of Islamic education above, a common thread can be drawn from the problems of Islamic education, namely:

1. There are still conceptual-theoretical or philosophical problems which then have an impact on practical operational problems.

2. This conceptual-theoretical problem is marked by the existence of a dichotomy paradigm in the world of Islamic education between religion and non-religion, revelation and reason and the world and the hereafter.

3. Lack of response of Islamic education to social reality so that students are far from their sociocultural environment. When they graduate from Islamic education institutions they will experience a social shock.

4. The handling of this problem is only piecemeal, not integral and comprehensive

5. In this case, just take the example of the problem of Islamic education, namely the conceptualtheoretical problem. In this case, it is explained that Islamic education is only based on the understanding of Islamic education which only emphasizes aspects of ukhrawi life that are separate from worldly life, or aspects of spiritual life that are separate from physical life.

6. Therefore, it will appear that there will be a distinction and separation between what is considered religion and non-religion, the sacred and the profane, between the world and the hereafter. This perspective that separates one another is called a dichotomous viewpoint.

7. The separation between science and religion should be stopped immediately and become an effort to unite the two in one integralistic education system. However, the issue of integrating science and religion in one educational system is not an easy problem, but must be based on strong philosophical thinking, so that it does not seem just a patchwork.

8. The first step that must be taken in making educational changes is to formulate a "philosophical basic framework of education" in accordance with Islamic teachings, then develop "empirically the principles" that underlie its implementation in an environmental context (socio-cultural). Philosophy of Integralism is part of Islamic philosophy. which is an alternative to the holistic view that developed in the postmodern era in western societies.

\section{Strategies Offered to Overcome Future Islamic Education Problems}

So that Islamic education can overcome the problems of Islamic knowledge and face the challenges of globalization in the future, the strategies that need to be carried out are:

1. Establish a True Islamic Education Paradigm

Conduct in-depth studies to rebuild the paradigm of Islamic education following the true spirit of 'ruhul Islam.' Islamic culture rests on the Qur'an and As-Sunnah. Islamic education must be based on the view that Allah SWT sent down 'verses and 'His knowledge through two channels: formal channels through the procedures of Allah - angels - Apostles; which is referred to as 'ayatul qauliyah (Revelation, 
Al-Qur'an), and ayatul kauniyah (universe). Verse qauliyah is a guide, while ayat al kauniyah is a facility, a means of life (wasailul hayah). With this paradigm, then in Islamic education will not experience disintegration or dichotomics.

All the objects of discussion (in the curriculum) are seen as 'Allah's knowledge that must be learned to get the provision of Instructions for Life (study 'ayatul qauliyah) and get requirements to obtain living facilities (studying kauniyah). Besides, Islamic education must be holistic and integralists, that is, it must be oriented to the formation of a whole person. Therefore, Islamic educational material contains the unity of physical education, honing intellectual, emotional and spiritual intelligence, theoretical and practical instructional units, individual-social education units, and religious education material units (diniyah), philosophy, ethics, and aesthetics (morals ). Evaluation of Islamic education is also carried out within the framework of the unity of knowledge, attitudes, and behavior.

2. Carry out Affective Education

Affective education is the process of instilling value to students so that students are expected to be able to behave following applicable norms. Training that emphasizes emotional skills will foster solid religious awareness. He will refuse to do unlawful acts and even try to prevent them with all his might and efforts. Affective education or learning is a learning activity that is directed to form attitudes that are based on the values of religious teachings (Islam) giving birth to a noble character in the lives of students, not only the influence of education that takes place in schools, but also in families, and society. 3. Improve the quality of teaching staff

The teacher is the backbone of education. Therefore, the quality of teachers must obtain certainty and guarantee of their professional competence. Building training centres and developing teacher quality has dramatically helped to provide reliable teaching staff. Also, the existence of centres for teacher quality development will facilitate the exchange of experiences and the sharing of ideas and ideas.

\section{CONCLUSION}

Islamic strategies and tactics must be more effective and efficient, meaning pedagogical, sociological, and cultural. Therefore, the Islamic breath in the person of a Muslim is essential to be able to move the behaviour reinforced with extensive knowledge so that he can provide appropriate and useful answers to the challenges of the development of science and technology, and in Islamic education will not be separated from Islamic principles sourced from the basic principles of the Koran. Planning for future education must include three main characteristics of a society, namely: the future of socio, the future of techno, and the future of bio.

Besides, Islamic education strategies in facing future challenges include: (1) Building an actual Islamic Education paradigm; (2) Carry out Affective Education; and (3) Improving the quality of teaching staff.

\section{REFERENCES}

Arifin, Muzayyin. (2003). Kapita Selekta Pendidikan Islam. Jakarta: Bumi Aksara.

Azra, A. (2002). Pendidikan Islam Tradisi dan Modernisasi Menuju Milenium Baru. Jakarta: Logos Wacana Ilmu.

Baharudin. (2011). Pendidikan Islam dan Isu-Isu Sosial. Yogyakarta: Kurnia Kalam Semesta.

Bakry, Sama'un. (2005). Menggagas Konsep Ilmu Pendidikan Islam. Bandung: Pustaka Bani Quraisy,.

Daulay, Haidar Putra. (2004). Pendidikan Islam: Dalam Sistem Pendidikan Nasional di Indonesia. Jakarta: Kencana.

Faisal, J. A. (1995). Reorientasi Pendidikan Islam. Jakarta: Gema Insani Press.

Ilham, D. (2020). Persoalan-Persoalan Pendidikan dalam Kajian Filsafat Pendidikan Islam. Didaktika: Jurnal Kependidikan, 9(2), 179-188.

Langgulung, H. (1980). Beberapa Pemikiran tentang Pendidikan Islam. Bandung : al-Ma'arif. 
Mahzar, Armahedi. (1998). Ilmu Pendidikan Islam. Jakarta: Kalam Mulia.

Mas'ud, Abdurrahman. (1993). Beberapa Aspek Dasar Kependidikan. Jakarta: Bina Aksara.

Mastuhu. (1999). Memberdayakan Sistem Pendidikan Islam. Jakarta: Logos Wacana Ilmu.

Muhaimin. (2013). Rekonstruksi Pendidikan Islam; Dari Paradigma Pengembangan, Manajemen Kelembagaan, Kurikulum hingga Strategi Pembelajaran. Jakarta: Rajawali Pers,.

Muhaimin. (2006). Pendidikan Islam. Bandung: Pustaka Setia,.

Muslim, K. d. (2008). Paradigma Baru Pendidikan: Restropeksi dan Proyeksi Modernisasi Pendidikan Islam di Indonesia. Jakarta : IISEP.

Nata, A. (2003). Manajemen Pendidikan: Mengatasi Kelemahan Pendidikan Islam di Indonesia, : , Jakarta: Prenada Media.

Rembangy, Musthofa,. (2010). Pendidikan Transformatif: Pergulatan Kritis Merumuskan Pendidikan di Tengah Pusaran Arus Globalisasi. Yogyakarta: Teras.

Sanaky, H. A. (1997). Pendidikan Islam di Indonesia Suatu Kajian Upaya Membangun Masa Depan" Pendidikan Islam dalam Peradaban Industrial. Yogyakarta : Aditya Media.

Sanjaya, Wina. (2009). Strategi Pembelajaran Berorientasi Standar Proses Pendidikan. Jakarta: Kencana.

Syah, Muhibbin. (1997). Psikologi Pendidikan dengan Pendekatan Baru. Bandung: Remaja Rosdakarya.

Zamroni. (2000). Paradigma Pendidikan Masa Depan. Yogyakarta: BIGRAF Publishing. 